This item was submitted to Loughborough's Research Repository by the author.

Items in Figshare are protected by copyright, with all rights reserved, unless otherwise indicated.

\title{
Storm-water management in low-income countries
}

PLEASE CITE THE PUBLISHED VERSION

http://dx.doi.org/10.1680/muen.12.00029

PUBLISHER

(C) ICE Publishing

VERSION

VoR (Version of Record)

LICENCE

CC BY-NC-ND 4.0

REPOSITORY RECORD

Reed, Brian. 2019. "Storm-water Management in Low-income Countries". figshare.

https://hdl.handle.net/2134/26183. 


\section{Storm-water management in low-income countries}

Brian Reed BSC Hons (Dunelm), MSc, CEng, CEnv, CWEM, MICE, MCIWEM, FHEA

Lecturer, Water, Engineering and Development Centre, School of Civil and

Building Engineering, Loughborough University, Leicestershire, UK

Rapid urbanisation coupled with a changing climate is increasing surface run-off in many cities in low-income countries. Badly managed run-off has a disproportionate impact on the poor. In a series of ten research projects the state of storm-water management in Vietnam, Nigeria, Uganda, Kenya, Pakistan and India has been examined, including issues of management, maintenance, health impacts (such as malaria) and design standards. The findings show that institutional issues such as urban planning, financing, management responsibility and skills levels are areas that require attention if storm-water is to be controlled effectively. Integrated approaches are required, making institutional coordination critical. Technical issues also need to be addressed, with silt and solid waste being a significant design problem.

\section{Introduction}

The management of water in urban areas is dominated by a focus on water supply, with foul waste water in a distant second place: surface water drainage is very much an afterthought. In the UK, urban flooding, the problem of diffuse pollution and the promotion of new control methods under the banner of sustainable (urban) drainage systems (Suds) have recently highlighted the issue of rainwater management. This uneven pattern in priorities is even more pronounced in low-income and middle-income countries. The demand for water supplies means that water consumption is increasing in advance of sanitation provision. On-site sanitation facilities such as septic tanks and pit latrines can address the containment of excreta to some extent, but the septage and sullage resulting from a reasonable consumption of water ends up in surface drains and natural watercourses, creating a pollution hazard. This is in addition to the management of large volumes of rainwater, which can be significant in tropical areas.

\subsection{Challenges in research}

The academic and practitioner literature relating to urban drainage in low-income countries is notable by its limited quantity. There are only two specific text books (Cairncross and Ouano, 1991; Parkinson and Mark, 2005), a detailed review of drainage performance (Kolsky, 1998) and a series of monographs (Tucci, 2001). Due to the lack of documentation, many of the journal papers that have been written are introductory with the same issues being observed (e.g. Silveira, 2002), and with a tendency to discuss technical or hydrological aspects (Armitage, 2011). There are some detailed studies on specific aspects (e.g. Marais and Armitage (2003) on solid waste, Kolsky (1998) on blockages in covered drains, Lindsay et al. (2004) on malaria control). Literature searches are hampered by the range of terms used (e.g. surface/surface water/road/urban/municipal/ rain/rainwater/storm/storm-water + drainage/run-off/control/ management) or as drainage being a subset of another activity (e.g. malaria control, flood control, road design and environmental sanitation). Agricultural drainage is fundamentally different although occasionally information from this field can be relevant.

\section{Methodology}

This paper is a summary of a Department for International Development (DFID) scoping project (Reed, 2004) and a series of subsequent postgraduate dissertations carried out since 2008 (Table 1). These consisted of a desk study (literature review, examination of grey literature and interviews) and, in some cases, field visits to gather primary material. Each project took a citywide perspective, looking at various socio-economic areas, except Reed (2010) and Siddiqui (2008), where the studies focused solely on low-income areas. These unpublished project reports are available in the Water, Engineering and Development Centre Resource Centre, in the School of Civil and Building Engineering, Loughborough University (http://wedc.lboro.ac. uk/knowledge/resources_centre.html).

In an attempt to provide some order to an inherently multidisciplinary subject, a sustainable livelihoods model (Ashley and Carney, 1999) has been used to provide some structure to this paper, first discussing the wider context and trends, then examining issues under headings of human, social, economic, environmental and physical factors, followed by a discussion of the enabling environment. As such, this paper presents a review of the state of urban drainage in 


\begin{tabular}{|c|c|c|c|c|}
\hline Author & Date & Title & Location & Methodology \\
\hline Abdullahi & 2008 & $\begin{array}{l}\text { Management and Maintenance of } \\
\text { Urban Drainage: a Case Study of } \\
\text { Lagos, Nigeria }\end{array}$ & Lagos, Nigeria & Desk study and field visit \\
\hline Alhaji Isa & 2010 & $\begin{array}{l}\text { Sandstorms as a Source of Sediment } \\
\text { in Urban Drainage Systems in } \\
\text { Low-Income Countries (Case } \\
\text { Study of Maiduguri, Nigeria) }\end{array}$ & Maiduguri, Nigeria & Desk study and field visit \\
\hline Chido-Amajuoyi & 2010 & $\begin{array}{l}\text { Sediment Impact on Urban Drainage } \\
\text { in Low-Income Countries: a Case } \\
\text { Study of Jos Plateau State, Nigeria }\end{array}$ & Jos, Nigeria & Desk study and field visit \\
\hline Chaturvedi & 2010 & $\begin{array}{l}\text { Review of Water and Drainage Services } \\
\text { for Ghaziabad City and SUDS Potential } \\
\text { in India }\end{array}$ & Ghaziabad, India & Desk study \\
\hline Gómez Vega & 2008 & Urban Drainage and Malaria Control & global & Desk study \\
\hline Khan & 2011 & $\begin{array}{l}\text { Identification of Issues to Urban } \\
\text { Storm-Water Drainage Standards } \\
\text { and Specifications: A Case Study of } \\
\text { Pakistan }\end{array}$ & Pakistan & Desk study \\
\hline Reed & 2004 & $\begin{array}{l}\text { Sustainable Urban Drainage in } \\
\text { Low-Income Countries - a Scoping } \\
\text { Study; Project Report }\end{array}$ & $\begin{array}{l}\text { Uganda, Brazil, } \\
\text { Vietnam }\end{array}$ & Desk study and field visit \\
\hline Reed & 2010 & $\begin{array}{l}\text { Confidential Project Report on } \\
\text { 'Integrated Approaches to Reducing } \\
\text { Poverty and Improving Health in } \\
\text { Informal Settlements of Nairobi' for } \\
\text { Practical Action }\end{array}$ & Nairobi, Kenya & Field visit \\
\hline Rizvi & 2011 & $\begin{array}{l}\text { The Issues and Urban Stormwater } \\
\text { Management in Karachi, Pakistan }\end{array}$ & Karachi, Pakistan & Desk study \\
\hline Rwabwogo & 2011 & $\begin{array}{l}\text { Applicability and Appropriateness of } \\
\text { Sustainable Stormwater Management } \\
\text { Systems in the Developing World }\end{array}$ & Kampala, Uganda & Desk study and field visit \\
\hline Siddiqui & 2008 & $\begin{array}{l}\text { Environmental Health Impacts of Living } \\
\text { along Drain in Urban Area - Karachi } \\
\text { Pakistan }\end{array}$ & Karachi, Pakistan & Desk study and field visit \\
\hline
\end{tabular}

Table 1. Location and methodology of research dissertations

low-income countries rather than the detailed findings of any of the specific dissertations.

\section{Urban drainage}

This paper will only briefly introduce the context of urban drainage in low-income and middle-income countries, as these have been discussed in detail elsewhere (Parkinson and Mark, 2005; Tucci, 2001). The pattern is one of mostly open drains, lined or unlined, running adjacent to roads and generally being managed by the roads department of the city or town council. The drains may not necessarily form a network. These channels have to cope with intense rainfalls on a regular basis, although relevant design data may not be available. They are often filled with solid waste (litter and silt) deliberately or through erosion. Informal unplanned areas often have no drainage provision and the residents adopt various strategies to cope. Water-related diseases such as diarrhoea and malaria are common and are linked to poor drainage.

\section{Global trends}

Urbanisation is a global phenomenon. More people are living in cities and the urban population is rising fast. Competition for land means that the poorer sections of society often choose to live in areas that are cheap and close to work opportunities but that are vulnerable to flooding, landslips or pollution. These settlements are often illegal as planners realise that they 
Municipal Engineer

Volume 166 Issue ME2
Storm-water management in

low-income countries

Reed are not environmentally suitable for housing. The increase in the urban population is forcing people into living in more and more marginal areas. Urban growth also increases the impermeable area, creating more run-off. Existing drains are overwhelmed by higher flows. Public infrastructure such as sewers and solid waste collections is often lacking in many areas of towns in low-income countries and this situation is exacerbated where the legal, financial and environmental situation makes provision even more problematic, even if there are funds and the political will to address the issue.

The increasing urban population is consuming more water, and rising standards of living increase the amount of consumption per person. Industrial growth also demands more water. The provision of water supplies is not matched by the provision of waste water disposal systems, so much of the used water ends up in the formerly natural drainage channels, either directly or via septic tanks, latrines or open defecation, killing the river ecologically and often ending up with the river being canalised, culverted and eventually buried, a fate that has occurred to rivers such as the Fleet and the Westbourne in London. Solid waste is also poorly managed and can end up in drainage channels either through direct dumping or being blown or washed into the drain. Water supply and waste come together as the increased use of plastic bottles and sachets of water leads to them being dropped as litter and ending up in drains.

Climate change will have various impacts on urban drainage. Increased rainfall will increase run-off; increased intensity will increase sediment transport; less frequent rainfall will increase the build-up of surface detritus to be washed into drains each storm. Increasing uncertainty will make predicting design parameters more difficult. High, intense, unpredictable rainfall already makes drainage in tropical countries different from that in temperate areas and climate change will increase these problems. Climate change may also lead to major population movements, adding to the trend towards urbanisation.

\section{Individual human impacts}

Flooding, especially of traffic routes, is a common indicator of poor drainage management. However, being delayed for a couple of hours going to work (Chido-Amajuoyi, 2010) or pedestrians being splashed by cars (Alhaji Isa, 2010) is a minor inconvenience compared with the impact of flooding on those whose only option is to live alongside a major drain. Siddiqui (2008) gives a graphic account of the lives of people living alongside nullahs (open drains) in Karachi, Pakistan. From a series of observations, interviews and questionnaires, she describes the impact of malaria, typhoid, diarrhoea, scabies and other skin complaints resulting from living in proximity to a polluted drain. She notes that children had to be tied to furniture to stop them falling into the nullah and drowning. Flood waters damage possessions, such as personal papers and identity cards, furniture, electrical goods and even the structure of the house. Rwabwogo (2011) notes the poorest houses suffered most as they were made from mud. The human misery of flooding is compounded by the filthy water, contaminated with excreta and industrial waste water (Figure 1).

Scarce private money is spent on building bunds and raising floor levels to avoid the flood waters, but the continued siltation of the nullah makes the flooding worse. Siddiqui (2008) tries to collate living near the nullah with various socioeconomic factors. Poor housing condition is related to living near the drain but the direct impact on health is not so clear. Rwabwogo (2011) notes the physical danger of falling into open drains next to roads. This is more of a problem when no safe crossing points are provided (Figure 2).

Gómez Vega (2008) attempts to examine the health aspects specifically. Although she tried to look at links between poor drainage and various diseases such as cholera and hookworm, the lack of literature resulted in the author focusing on mosquitoes, especially in relation to malaria. Here she found a wealth of material, very little of which was current. As an example, in the ICE library there are 14 significant publications on malaria pre-1960 compared with five produced after that date. The advent of dichlorodiphenyltrichloroethane seems to have killed off the municipal malaria engineer but not the mosquito. There is some guidance on environmental management for mosquito control (WHO, 1982) but this focused on agricultural and water resources practices rather than the urban context. A small but persuasive literature exists, extolling the importance and utility of environmental controls such as drainage management on mosquito control (Lindsay et al., 2004), but the current orthodoxy for malaria control

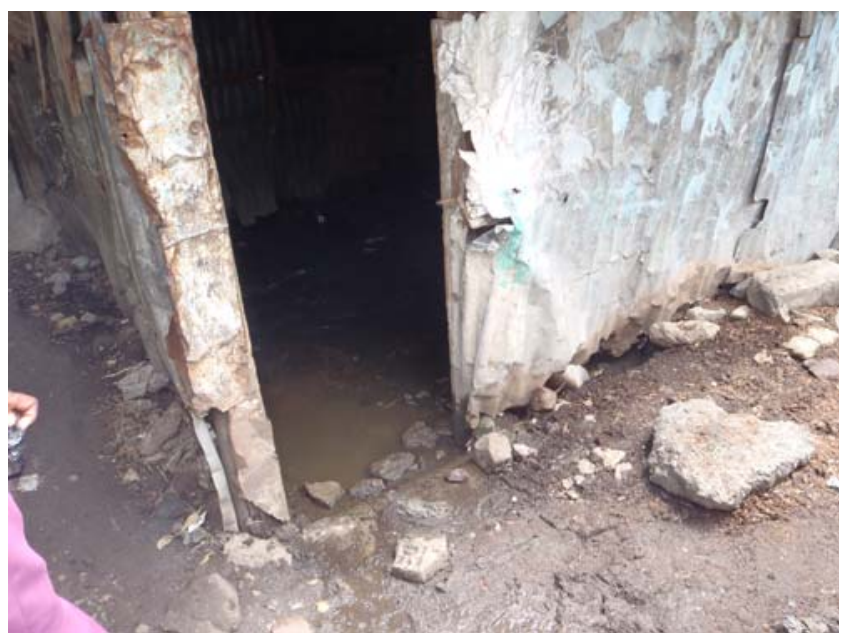

Figure 1. House flooded due to blocked drain, Mukuru, Nairobi, Kenya (photograph: B Reed) 
Storm-water management in

low-income countries

Reed

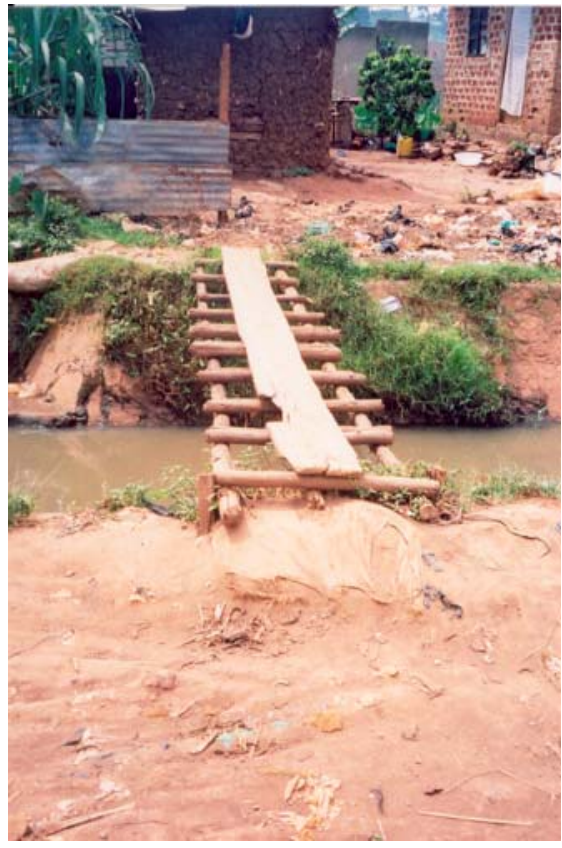

Figure 2. Drains require safe crossing points, Kampala, Uganda (photograph: B Reed)

from Gómez Vega's research seems to rely on treated bed nets and continued use of insecticides. Lack of information about effective environmental control techniques and the high capital cost of drainage (but lower life-time costs) seemed to discourage uptake of proven methods (Utzinger et al., 2001).

\section{Social factors}

Alhaji Isa (2010) found that people who lived in areas that were poorly drained complained that family and friends did not visit. Siddiqui (2008) heard that parents had difficulty finding husbands for their daughters if they lived next to the drain. Abdullahi (2008) observed a loss of 'civic pride' in areas that had poor environmental conditions. Chido-Amajuoyi (2010) reported that blocked drains were regarded as an 'eyesore' and 'smelly'. Chaturvedi (2010) noted that some residents actually filled in the drains in front of their houses to stop them being filled with rubbish and stagnant water. Rwabwogo (2011) found that people in Uganda seemed to prefer closed drains but did not understand that these discharged into open watercourses, which in turn were seen as sources of mosquitoes, damaging to homes, a safety hazard if the channel was open, damaging to roads, and damaging to wetlands. They were also not sure which organisation was in charge of drainage, with the water and sewerage corporation being incorrectly assumed to be responsible.
Chido-Amajuoyi (2010) compared high- and low-income areas of Jos, Nigeria and found the level of municipal service differed considerably, mainly in terms of solid waste management, which had a direct impact on drainage performance in betteroff areas. This was due to better collection services and household practices, such as storing waste until it was collected, illustrating that solid waste blockages can be prevented. Alhaji Isa (2010) found that preferential treatment (in terms of street sweeping) was given to areas that voted for particular political parties. The street sweepers were all middleaged women without adequate safety clothing or tools to carry out the task efficiently, a pattern seen elsewhere in the world (Figure 3).

\section{Economic overview}

As this subject is so interrelated with other factors, getting an economic overview of the costs and benefits of drainage has proved difficult. Abdullahi (2008), Rwabwogo (2011) and Rizvi (2011) carried out reviews at city level (Lagos, Kampala and Karachi, respectively). They found adverse economic impacts relating to flooding, especially when traffic was disrupted. Drinking water quality was at risk from both polluted water resources and damage to distribution systems. Many of the costs of poor drainage were considered as discrete issues rather than being aggregated. Chido-Amajuoyi (2010) found that poor drainage increased building costs as foundations had to be strengthened. Economic models for mosquito control compared environmental management with other health interventions, but did not offset the cost of drainage with other benefits it can bring (Utzinger et al., 2001).

It has been observed that drains do have an economic role to play besides preventing damage or providing work for the construction industry. In Vietnam people were observed using

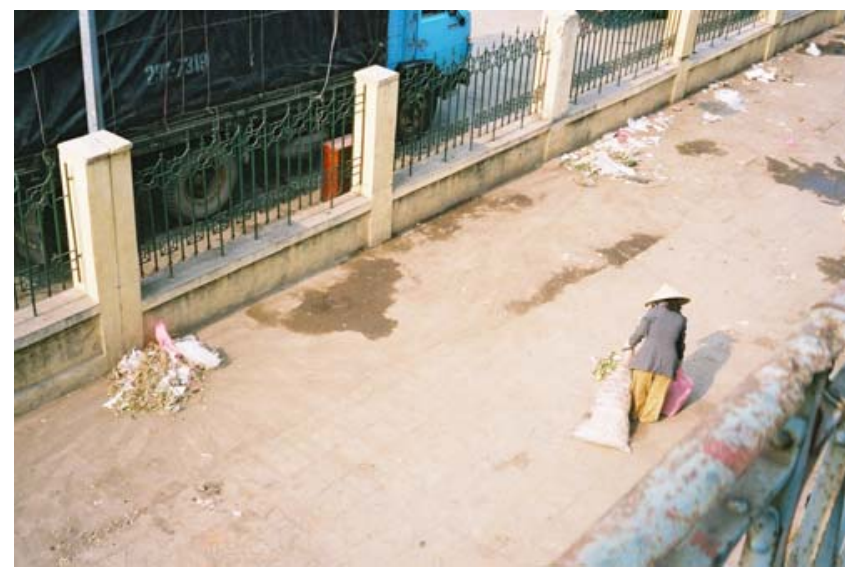

Figure 3. Street sweeping protects surface water quality, Hanoi, Vietnam (photograph: B Reed) 
Municipal Engineer

Volume 166 Issue ME2
Storm-water management in

low-income countries

Reed water for irrigation and fishing (Reed, 2004). In Uganda people were washing clothes (Figure 4) and cars using the drain. In Nigeria the sediment taken from drains was reused in building (Chido-Amajuoyi, 2010). In Karachi boys dived into the drainage canals to retrieve discarded items to sell (Siddiqui, 2008).

Information on drainage budgets was considered too sensitive to be made public, assuming the information was available. Chido-Amajuoyi (2010) found that the road maintenance agency did not have specific data on budgets for drain cleaning, which was carried out by road sweepers. Part of the problem was the lack of solid waste management, as residents had nowhere to dispose of rubbish apart from the roadside and drain, thus increasing the cost of road sweeping as a result of institutional failures elsewhere. Abdullahi (2008) reports that budgets were declining and that expenditure was significantly less than the funds allocated, with payments for projects being delayed to the extent that the contractor abandoned work. One case study (Reed, 2004) was in the small Ugandan town of Lugazi, where the drain in the main commercial street had become so completely silted up that the road flooded regularly during rains. Local shopkeepers had moved, creating a drop in rents and rates as well as disrupting business. The town council was planning to spend a considerable sum on rebuilding the drain. This illustrates a common pattern of (excessive) expenditure after major flooding as opposed to smaller amounts being spent on long-term maintenance. Alhaji Isa (2010) found that funds for maintenance were released only when complaints were received and that delays in releasing funds actually added to the damage caused.

\section{Environmental overview}

There are many environmental factors related to drains (e.g. mosquito breeding, pollution, smell and flooding) but one

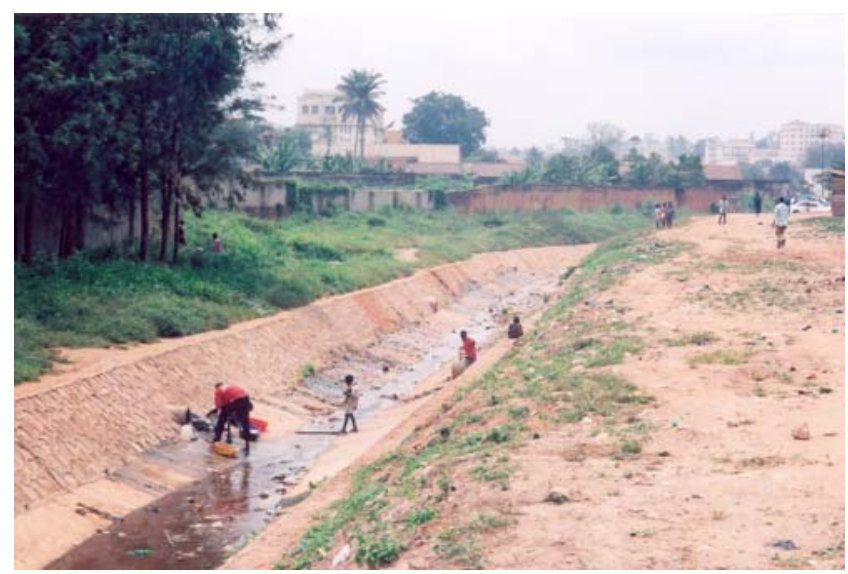

Figure 4. Washing laundry in a main drain, Kampala, Uganda (photograph: B Reed) commonly reported issue was the occurrence of solids in the drains. The initial scoping study (Reed, 2004) and subsequent projects Chido-Amajuoyi (2010) and Alhaji Isa (2010) found that, despite a general perception that drains were blocked by litter and large items of solid waste, most of the solids in the drains consisted of silt and sand (Figure 5). Plastic bags and bottles tended to float and create blockages at specific points (e.g. culverts, screens and where pipes crossed drains) and so were visible and obvious causes of localised failure. Marais and Armitage (2003) found that trash screens were not a sustainable method of controlling rubbish in drains and that wider solid waste management was the key.

Silt occurs for several reasons, such as unbound, earth roads, urban agriculture and high levels of construction activity. Alhaji Isa (2010) looked at the problem of sandstorms blocking drains in northern Nigeria. These often preceded rainstorms, resulting in the rain washing sand off roofs and roads into drains and causing blockages. Whatever the source of the silt, it needs to be either prevented from entering the drain in the first place or removed before it reduces the capacity of the drain excessively. The quantity of silt is several orders of magnitude greater than in industrialised countries and is exacerbated by long dry periods and infrequent road sweeping. Established methods of silt control, such as selfcleansing velocities, catch pits or gully pots are insignificant measures given the quantities involved. Chido-Amajuoyi (2010) reviewed road drains in Jos, Nigeria, and found that no structural measures were taken to control the ingress of silt, despite it being a key maintenance issue locally. He recommended erosion control as a more sustainable option to control sediment than either regular cleaning or sediment traps. Alhaji Isa (2010) reported that trees were planted

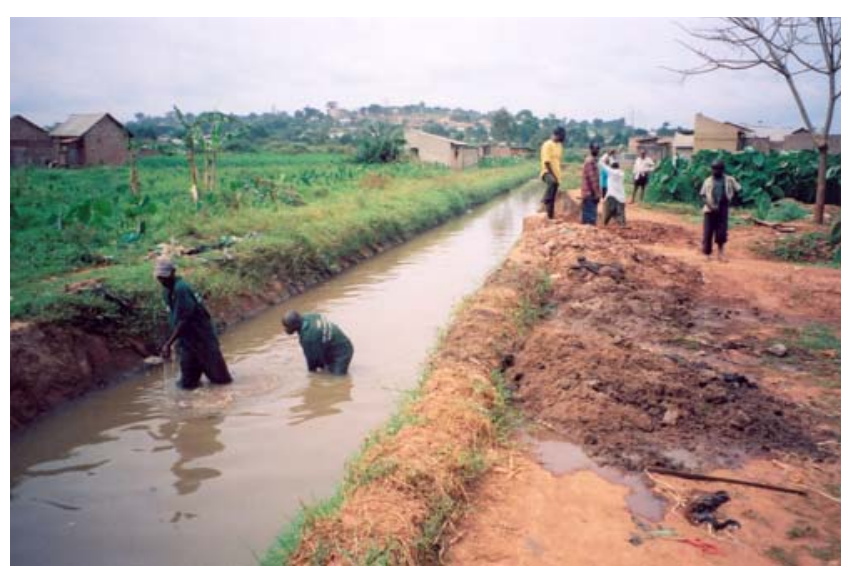

Figure 5. Removing silt from a drainage channel, Kampala, Uganda (photograph: B Reed) 
around the edge of the town as windbreaks to control the sandstorms.

Silt deposition was made worse if the soil excavated to make the drain was not taken away by the contractor and silt was not removed promptly from drains (Alhaji Isa, 2010). The author observed that contractors left piles of silt lying by the side of drain for over 4 weeks. Part of the reason for this was to allow the material to dry out (Figure 6) but it was also reported that this was a ploy to require the work to be repeated. ChidoAmajuoyi (2010) noted that silt left in piles by the sides of roads was a traffic hazard, especially at night.

Apart from the environmental issues of pollution and flooding reported in all the studies reviewed, Chaturvedi (2010) looked at large-scale infiltration as a way of safeguarding water resources in an area of declining groundwater levels. This has become mandatory for new buildings in some parts of India, harvesting rain from buildings and discharging it after basic filtration into soakaways and trenches, and it has been successful in recharging aquifers and reducing localised surface waterlogging.

\section{Physical overview}

Many of the research projects have focused on physical interventions. Rwabwogo (2011) assessed the design criteria for drains and found that the general advice was similar in both developed and developing nations, except that developing

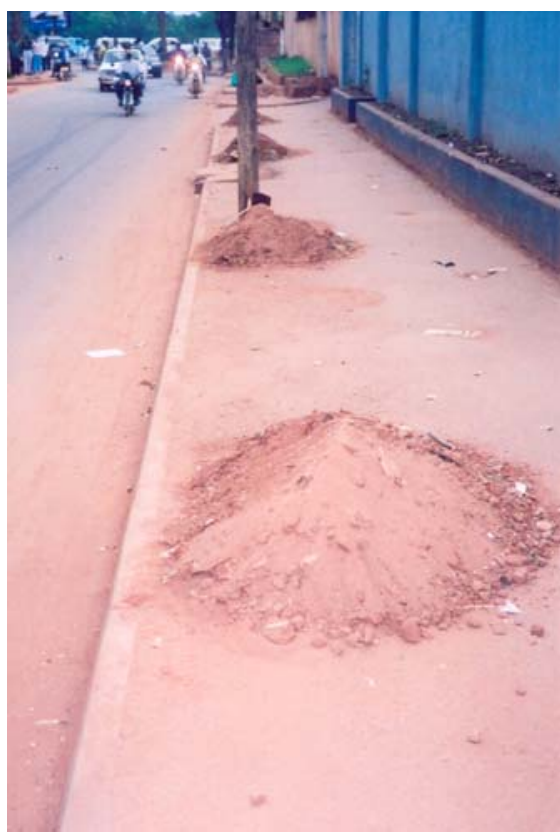

Figure 6. Piles of silt cleared from a drainage channel, Kampala, Uganda (photograph: B Reed) nations were encouraged to use open channels as they are cheaper to build and easier to clean. Khan (2011) examined the standards that are available and used in Pakistan. Lack of general guidelines has led each client (highway or development authority) to draw up their own guidelines or to adopt UK or US standards and textbooks, due to lack of expertise and attention to the area. Often even these local guidelines are not available. Foreign standards were seen as more advanced and therefore better. However, even if local standards existed, designers would have to know that they existed and be able to access them. One of Khan's interviewees commented on the lack of appropriate data available to enable systems to be designed efficiently. Even where the data were collected and were detailed enough (spatially and temporally), the administrative system did not always make them available.

A fundamental design issue observed in northern Nigeria was that drains were built as part of the road but not as a coordinated network, so tended to be isolated and to not necessarily have an outlet (Alhaji Isa, 2010), a pattern also observed by Rwabwogo (2011) in Uganda. The concept of a 'master plan' approach is flawed (Tayler et al., 2003) as

it is difficult to ensure that the city-wide drainage system is planned in its totality and the tendency is to get bits of planned drains in small areas which don't necessarily have proper outlets and not linking to the next stages of the network. (Cotton, quoted in Rizvi 2011)

This failure of conventional systems has led local people to find coping mechanisms to live with poor infrastructure, and researchers to examine the potential for other storm-water management techniques.

\section{Coping strategies}

One observation in low-income areas was a reversal of the practice of building drainage ditches and channels. Rather than digging down, water was diverted away from houses by bunds, often made from sandbags (Figure 7). Furniture, houses, latrines and buildings such as schools were raised up on platforms in areas that flooded frequently. Where properties adjoined a road that was at a higher level, banks were required to keep the road drains from discharging into houses.

Bunding alongside drainage channels occurs for several reasons. The banks may be deliberately built up to contain the water (Reed, 2004). A similar action occurs when drains are cleaned and the silt is deposited on the banks of the channel (Chido-Amajuoyi, 2010). A third reason is the dumping of general solid waste along the side of the drain, which compacts and forms a bund (Siddiqui, 2008). This method can contain water in the drain, but can prevent local run-off from entering the channel. Over time, the action of bunding and in-channel siltation raises the channel cross-sectional profile so that, when 
Storm-water management in

low-income countries

Reed

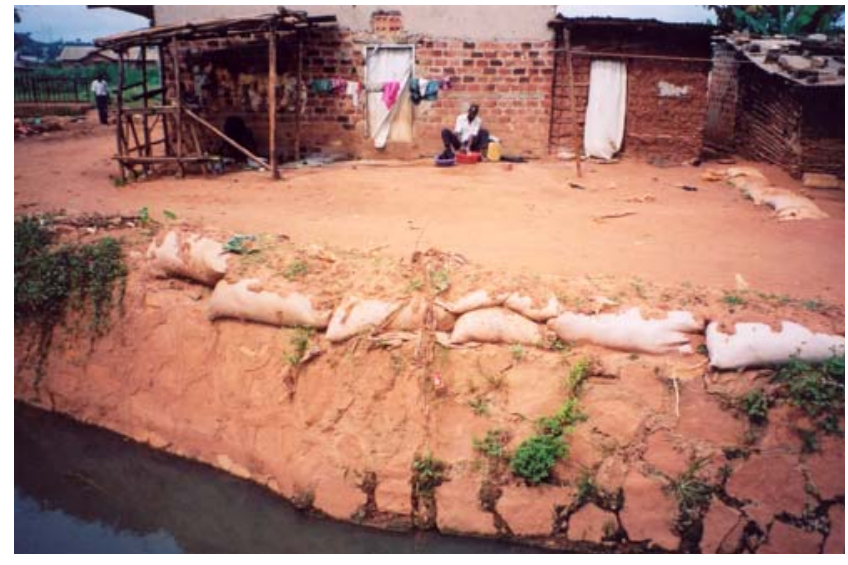

Figure 7. Sandbags protect property from overland flow, Kampala, Uganda (photograph: B Reed)

the channel does overflow, the lower-lying surrounding area is flooded (Figure 8).

\section{Alternative technologies}

Suds seem to have some potential in low-income countries, as they focus on on-plot or local-level activities and so can be constructed piecemeal rather than relying on a larger plan. This also makes them more suitable for community-level management. They do not require much (imported) equipment and can be constructed using labour-intensive techniques. The control of inherent silt is important, as is the attenuation of flows, both of which reduce the load on the drainage system downstream.

Suds such as detention basins have potential in attenuating heavy flows but are not suitable if the water is grossly contaminated with faecal or toxic industrial discharges (Goldenfum et al., 2007) or where mosquitoes are a concern. Rwabwogo (2011) noted that public and professional awareness and acceptance are just as important barriers as technical design factors. Goldenfum et al. (2007) noted that the failure of some Brazilian attempts to use Suds was due to poor design, inadequate education and poor regulations rather than the technology itself.

Chaturvedi (2010) looked at the potential of using Suds in India. He identified one set of devices that seemed to be successful. Intense monsoon rain is run-off before it can infiltrate the ground. This, coupled with excessive groundwater abstraction, is leading to dramatic falls in the water table level. Artificial recharge is being promoted to address this problem by combining rainwater-harvesting methods with modified soakaways and infiltration trenches. Rainwater from roofs is channelled directly into chambers that contain coarse filters and then allowed to soak into the ground, avoiding contamination from diffuse pollution.

Rather than seeing how Suds developed in industrialised countries could be used in low-income nations, the initial study
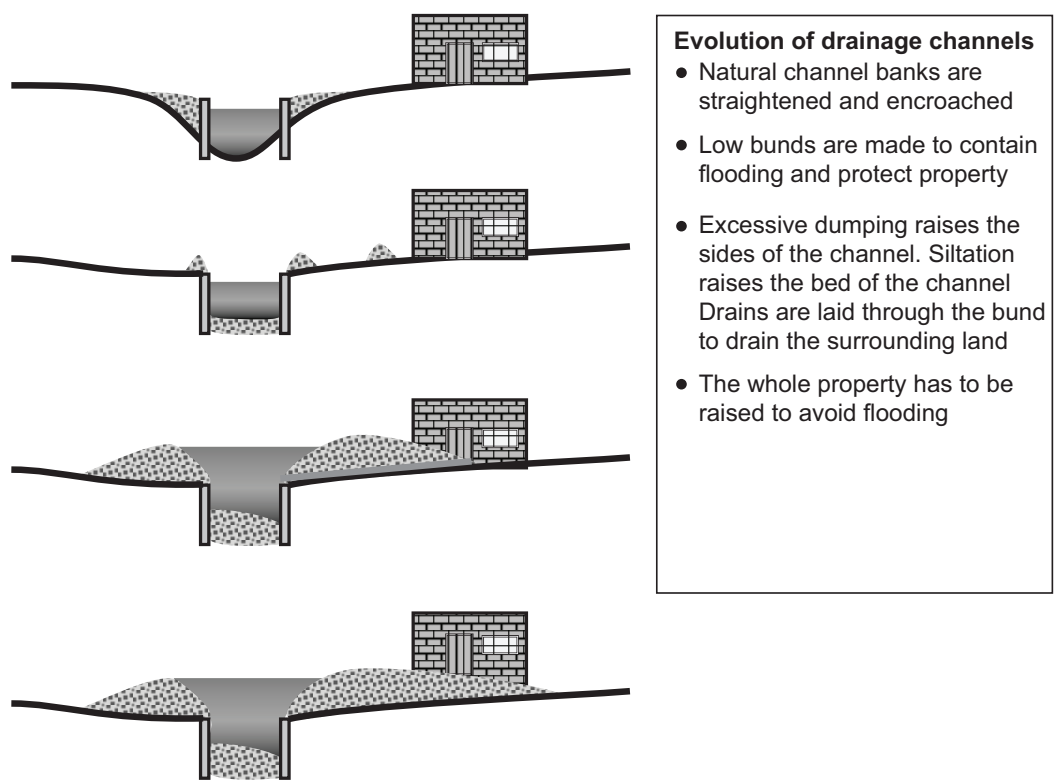

Figure 8. Bunding provides short-term protection but long-term vulnerability (based on Siddiqui, 2008) 
Storm-water management in

low-income countries

Reed
(Reed, 2004) noted that use was being made of Suds techniques, both formally and informally. Wide swales are used alongside main roads where space allows. Basic permeable pavements made from builders' rubble were seen to cope with shallow surface run-off, and existing urban lakes had an obvious impact on water quality (Figure 9).

\section{Enabling environment}

Armitage (2011) notes that most urban drainage literature does not look widely enough and consider issues such as sullage or governance. This latter issue was recognised in the initial scoping study (Reed, 2004), which included a series of workshops in Brazil, Uganda and Vietnam. One of the most significant findings was the lack of a clear lead in urban drainage management. The main unit of administration was the city or municipality rather than the hydrological catchment. Water passes from the householders' roof and land to the adjacent municipal road. The road drains lead the run-off away from the road, with the design focus on keeping the road clear of standing water, to the nearest point it can be discharged. A good example of this was in Kampala, where the existing main drain (constructed as part of malaria control in the mid-twentieth century) was being refurbished, and to improve the flow characteristics a wide channel was cut through the swamp that bordered Lake Victoria. As only $7 \cdot 3 \%$ of the city's residents are connected to the sewer (African Development Bank, 2008), the channel is grossly polluted. This polluted run-off is partially treated in the natural wetland before it reaches the lake and the nearby intake for the water treatment works for the city. The balance between protecting the water quality of the lake and the health of the residents and reducing flooding on key roads was complicated by the lack of holistic approaches. The de facto lead on urban drainage was the city council's road department, which only had a limited

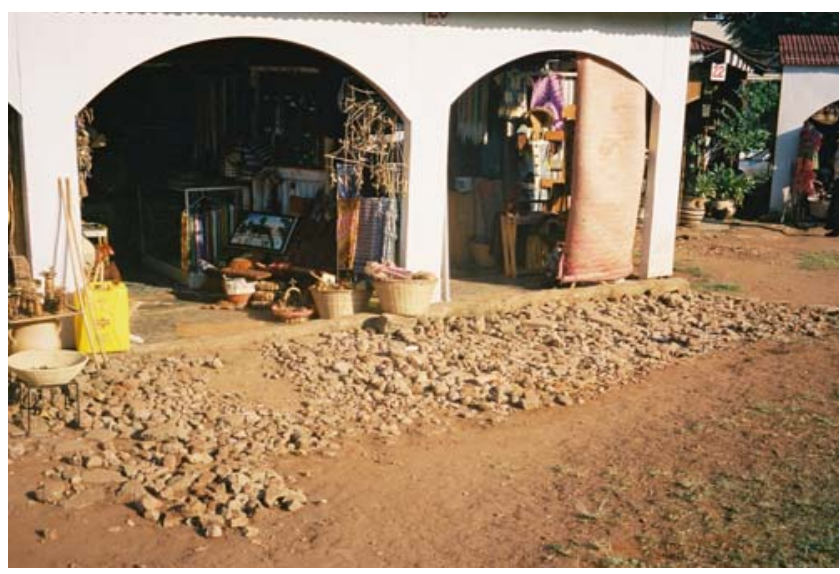

Figure 9. Builders' rubble creates an informal permeable surface, Kampala, Uganda (photograph: B Reed) remit, and limited economic and human resources to deal with surface water on roads. Drainage was an additional factor in road design rather than an important factor in itself. Drinking water quality, environmental protection, solid waste management, malaria control, flooding and other aspects were the responsibility of other public bodies.

Abdullahi (2008) found that in Lagos there were federal, state and local government contributions to road management and these were further divided by construction and maintenance, as well as an Office of Drainage Services and a Ministry of the Environment. A similar pattern of shared responsibility was apparent in Vietnam (Reed, 2004), where a series of urban lakes were regarded as recreational facilities, sources of fish, flood controls, treatment facilities and areas to be reclaimed for development. Chido-Amajuoyi (2010) found nine sets of formal and informal stakeholders specifically involved in just the management of drain clearing in Jos, Nigeria. He also recognised the importance of involving the planning department as unplanned construction was a major factor in disrupting drainage, with buildings being constructed across drainage channels.

Community involvement is often suggested as a way of ensuring maintenance is carried out in low-income areas (Cairncross and Ouano, 1991; Parkinson and Mark, 2005) but Chido-Amajuoyi (2010) found this only occurred 'in times of emergency' as it was a 'government responsibility'. Youths would clean drains if they could sell the silt to local builders. Poor areas lacked the tools to clear drains at all. Both he and Rwabwogo (2011) recommended that public participation be limited to community involvement in issues of public awareness (dropping litter) and feedback (reporting blockages) as any planned maintenance needed to be institutionalised and not left until an area flooded. Alhaji Isa (2010) found that, even if residents did find the tools and motivation to clear drains, the silt would be washed back into the drain, as they could not dispose of the material.

Another theme running through all these research topics is the low level of awareness and skills relating to the topic. At one of the original project workshops, a town planner commented that his training at university on this topic was limited to a single paragraph of lecture notes. The municipal engineer in Lugazi charged with reinstating the town's main drain had never come across drainage design at university and in Maiduguri, northern Nigeria, a municipal official commented 'the engineer who did the design of these drains is not qualified to be one', but the informant then said he preferred closed drains, which where harder to clean out (Alhaji Isa, 2010). At an institutional level, a community-based review of a water and sanitation scheme in an informal settlement (Reed, 2010) showed that improvements to water supply and the provision 
of latrines had been successful but that local people did want something done about surface run-off, an issue that had not been addressed in the design of the project.

\section{Lessons arising from the research projects}

The clearest message from this series of research projects is the lack of clear institutional leadership and responsibility. Competing interests, a lack of focus and single issue approaches negate any attempt at an integrated approach to urban surface water management in cities in developing countries. Better budgets or improved construction will not improve the situation until a more coordinated approach is taken. No evidence for effectively delegating responsibility to community groups has been found, partly as the technology used to date has to be managed as a whole at a citywide level.

Recognising the quality of the water is also important. Stormwater in low-income countries can be grossly polluted due to the lack of an alternative disposal route for sullage and septage. The importance of silt control has also been underplayed, with the main focus on the hydrological aspects needed for design rather than the operational requirements of keeping the drains clear. The visible problem of floating litter is probably less of an issue and is more easily addressed than with the constant erosion and deposition of silt, and the design of systems needs to take this into consideration.

Having said that technology is not the whole answer, there is a clear lack of guidance and training that hampers action when it is taken. This is required for a range of audiences, not just engineers, as the barriers to better storm-water management range across finance, laws and regulations, politics, public awareness, meteorology, planning, surveying and a host of public services. However, municipal engineers cannot wait until they have the correct solution to this increasing problem, as the lives of the most vulnerable of a city's residents are living in increasingly poor environmental conditions. This challenge has been around for over 150 years, as the following quote on the Nottingham cholera outbreak in 1832 shows (Chambers, quoted in McDonald, 1983).

\footnotetext{
Altogether there were 930 attested cases and 330 deaths. It was generally agreed at the time that the lower parts of the town had been the worst affected and that the higher streets, built on porous sandy rock, had been almost immune. It might be supposed that such a calamity would have driven home the obvious inference that the drainage and ventilation of the houses in the lower part of the town required attention; the town fathers, however, contented themselves by acquiring new burial grounds.
}

\section{Acknowledgements}

While the views and opinions are those of the author, this paper is based on research carried out by the author and funded by DFID (Reed, 2004) and Practical Action (Reed, 2010) and studies carried out by Idris Yahaya Abdullahi, Ayuba Alhaji Isa, Sanjay Kumar Chaturvedi, Chukwuemeka Chido-Amajuoyi, Gadea Gómez Vega, Mohammad Idress Khan, Syed Rizwan Ali Rizvi, Rabia Siddiqui and Barbra Rwabwogo. Thanks go to them for their insights and enthusiasm, and to Ian Smout, Andrew Cotton, M Sohail Khan and Tricia Jackson for the support they provided during the students' research project.

\section{REFERENCES}

Abdullahi IY (2008) Management and Maintenance of Urban Drainage: a Case Study of Lagos, Nigeria. MSc thesis, Loughborough University, Loughborough, UK.

African Development Bank (2008) Kampala Sanitation Program 2008. See http://www.afdb.org/en/projects-and-operations/ project-portfolio/project/p-ug-e00-008/ (accessed 31/05/12).

Alhaji Isa A (2010) Sandstorms as a Source of Sediment in Urban Drainage Systems in Low-Income Countries (Case Study of Maiduguri, Nigeria). MSc thesis, Loughborough University, Loughborough, UK.

Armitage N (2011) The challenges of sustainable urban drainage in developing countries. SWITCH Conference 2011: The Future of Urban Water, Paris, France. See http:// www.switchurbanwater.eu/outputs/pdfs/W2-2_GEN_PAP_ Challenges_of_sustainable_urban_drainage_in_developing countries.pdf (accessed 05/12/12).

Ashley C and Carney D (1999) Sustainable Livelihoods: Lessons from Early Experience. Department for International Development, London, UK.

Cairncross S and Ouano EAR (1991) Surface Water Drainage for Low-Income Communities. WHO, Geneva, Switzerland.

Chaturvedi SK (2010) Review of Water and Drainage Services for Ghaziabad City and SUDS Potential in India. MSc thesis, Loughborough University, Loughborough, UK.

Chido-Amajuoyi C (2010) Sediment Impact on Urban Drainage in Low-Income Countries: a Case Study of Jos Plateau State, Nigeria. MSc thesis, Loughborough University, Loughborough, UK.

Goldenfum JA, Tassi R, Meller A, Allasia DG and da Silveira AL (2007) Challenges for the sustainable urban stormwater management in developing countries: from basic education to technical and institutional issues. NOVATECH 2007: 6th International Conference on Sustainable Techniques and Strategies in Urban Water Management, Lyons, France.

Gómez Vega G (2008) Urban Drainage and Malaria Control. MSc thesis, Loughborough University, Loughborough, UK.

Khan MI (2011) Identification of Issues to Urban Storm-Water Drainage Standards and Specifications: A Case Study of Pakistan. MSc thesis. Loughborough University, Loughborough, UK.

Kolsky P (1998) Storm Drainage: an Engineering Guide to the 
Low-Cost Evaluation of System Performance, IT

Publications, London, UK.

Lindsay S, Kirby M, Baris E and Bos R (2004) Environmental Management for Malaria Control in the East Asia and Pacific Region. World Bank, Washington DC, USA.

McDonald JD (1983) 'Looking Back': Environmental Health in Nottingham, 1847-1983. Environmental Health Dept., Nottingham City Council, Nottingham, UK.

Marais M and Armitage N (2003) The Measurement and Reduction of Urban Litter Entering Stormwater Drainage Systems. Water Research Commission Report No TT211/ 03, Pretoria, South Africa. See http://www.wrc.org.za/ Knowledge $\% 20 \mathrm{Hub} \% 20$ Documents/Water $\% 20 \mathrm{SA} \%$ 20Journals/Manuscripts/2004/04/WaterSA_2004_04_6a. pdf (accessed 06/12/2012).

Parkinson J and Mark O (2005) Urban Stormwater Management in Developing Countries. IWA, London, UK.

Reed B (2004) Sustainable Urban Drainage in Low-Income Countries - a Scoping Study; Project Report, Unpublished project report for DFID. Loughborough University, Loughborough, UK.

Reed B (2010) Confidential Project Report on 'Integrated Approaches to Reducing Poverty and Improving Health in Informal Settlements of Nairobi. Unpublished evaluation report for Practical Action, Loughborough University, Loughborough, UK.
Rizvi SR (2011) The Issues and Urban Stormwater Management in Karachi, Pakistan 2. MSc thesis, Loughborough University, Loughborough, UK.

Rwabwogo B (2011) Applicability and Appropriateness of Sustainable Stormwater Management Systems in the Developing World. MSc thesis, Loughborough University, Loughborough, UK.

Siddiqui R (2008) Environmental Health Impacts of Living along Drain in Urban Area - Karachi Pakistan. MSc thesis, Loughborough University, Loughborough, UK.

Silveira AL (2002) Problems of modern urban drainage in developing countries. Water Science and Technology 45(7): 31-40.

Tayler K, Parkinson J and Colin J (2003) Urban Sanitation: $a$ Guide to Strategic Planning. ITDG, London, UK.

Tucci CEM (ed.) (2001) Urban drainage in the humid tropics. UNESCO International Hydrological Programme.

Technical Documents in Hydrology 40(1): UNESCO, Paris, France.

Utzinger J, Tozan Y and Singer BH (2001) Efficacy and costeffectiveness of environmental management for malaria control. Tropical Medicine \& International Health 6(9): 677-687.

WHO (World Health Organization) (1982) Manual on Environmental Management for Malaria Control with Emphasis on Malaria Vectors. WHO, Geneva, Switzerland.

\section{WHAT DO YOU THINK?}

To discuss this paper, please email up to 500 words to the editor at journals@ice.org.uk. Your contribution will be forwarded to the author(s) for a reply and, if considered appropriate by the editorial panel, will be published as discussion in a future issue of the journal.

Proceedings journals rely entirely on contributions sent in by civil engineering professionals, academics and students. Papers should be 2000-5000 words long (briefing papers should be $1000-2000$ words long), with adequate illustrations and references. You can submit your paper online via www.icevirtuallibrary.com/content/journals, where you will also find detailed author guidelines. 